\title{
0 "BURITI" E OS BURITIS: BREVE ESTUDO SOBRE A OBRA DE GUIMARÃES ROSA E A CULTURA E A MITOLOGIA DOS POVOS ORIGINÁRIOS DAS AMÉRICAS
}

http://dx.doi.org/10.11606/issn.2237-1184.v0i32p127-147

Edinael Sanches Rocha ${ }^{\mathrm{I}}$

RESUMO

Esse artigo analisa as relações de sentido entre a novela "Buriti", de João Guimarães Rosa, e a cultura dos povos originários da América. A partir da leitura estilística da obra, cotejada com textos que trazem parte da tradição das culturas nativas, esse estudo propõe novas perspectivas interpretativas para a novela rosiana.

\section{ABSTRACT}

This article analyses the relationships of meaning between João Guimarães Rosa's novella "Buriti" and the culture of the indigenous peoples of the Americas. Based on the stylistic reading of the work, collated with texts that convey part of the tradition of the native cultures, this study aims at proposing a new interpretive perspective to Rosa's novella.
PALAVRAS-CHAVE:

"Buriti";

Mitologia ameríndia;

Guimarães Rosa.

\section{KEYWORDS}

"Buriti";

Indigenous mythology;

Guimarães Rosa.

I Universidade de São Paulo, São Paulo, São Paulo, Brasil. 


\section{$\int$ ntrodução}

Publicada em 1956, no Corpo de baile, "Buriti" apresenta poucas, mas significativas, indicações sobre possíveis relações de sentido entre o texto rosiano e a tradição dos povos originários das Américas. Tendo como foco o buriti, palmeira nativa que nomeia a narrativa, o presente texto analisa algumas relações de sentido entre a novela rosiana e parte dessa tradição.

Nesse estudo, a análise estilística do texto literário é articulada com a leitura dos textos que registram os mitos e hábitos culturais dos povos originários, num exercício de literatura comparada, nos termos de Leila Perrone-Moisés (1990, p. 91): “qualquer estudo que incida sobre as relações entre duas ou mais literaturas nacionais pertence ao âmbito da literatura comparada".

Para essa autora:

O objetivo dos estudos de intertextualidade é examinar de que modo ocorre essa produção do novo texto, os processos de rapto, absorção e integração de elementos alheios na criação da obra nova. Para Kristeva, portanto, as "fontes" deixam de interessar por elas mesmas; elas só interessam para que se possa verificar como elas foram usadas, transformadas. (Idem, p. 94)

Seguindo esse parâmetro ao longo desse ensaio, podemos oferecer ao leitor novas perspectivas interpretativas para a obra do escritor mineiro, à medida que fizermos o cotejo do texto literário com as "fontes" das diversas tradições.

Para que o leitor se situe minimamente em relação ao que será analisado a seguir, convém apresentar um breve resumo da trama narrativa de "Buriti".

Composta de três partes, a novela se inicia com a volta de Miguel, o Miguilim de "Campo geral", ao Buriti Bom, cenário da ação. Enquanto se aproxima da propriedade, o rapaz se lembra da primeira visita, ocorrida pouco mais de um ano antes. Nesse movimento de aproximação espacial e recuo temporal, via rememoração, desenvolve-se a primeira parte da novela.

Sobem ao palco os personagens da trama, ora pela perspectiva de Miguel, ora por meio do narrador em terceira pessoa, contando ainda com a intervenção de outra personagem, Gualberto Gaspar, casado com DonaDona, sem descendentes, tendo em vista a esterilidade do sertanejo. Esse é vizinho e compadre do proprietário do Buriti Bom, iô Liodoro. Apresentam-se as filhas do patriarca, Maria Behú - destituída de atrativos 
físicos, vive entre rezas e penitências - e Maria da Glória - bela e legítima herdeira da índole erótica do pai. Leandra, também chamada Lalinha, jovem citadina e nora de iô Liodoro, espera a volta do ex-marido, Irvino, após o casamento desfeito. Há também Ísio, filho de Liodoro que é amasiado com uma ex-prostituta, iá-Dijina, que mora em propriedade vizinha. Completando o quadro, aparecem o Chefe Zequiel, lunático que vive dos favores da família de Liodoro, enquanto passa as noites em claro escutando os sons noturnos; o Inspetor, espécie de agregado da propriedade; sua mulher, Dionéia, uma das amantes de Liodoro; e ainda Alcina, mulata trazida para o deleite do patriarca, uma de suas mulheres "exatas". Elementos da paisagem destacam-se e dão ao espaço físico da ação um tom de excepcionalidade, a saber, o Buriti Grande, descomunal em seu tamanho, e o Brejo do Umbigo, sua contrapartida feminina.

A segunda parte se dá durante o intervalo entre a primeira vinda de Miguel e seu retorno. $O$ narrador em terceira pessoa adota com frequência a perspectiva de Lalinha. A jovem reflete longamente sobre o amor e o desejo, reflexo do apaixonamento de Maria de Glória por Miguel. Há ocasião para o aparecimento de uma nova personagem, Do-Nhã, pseudofeiticeira chamada para fazer um "trabalho" pela volta de Irvino e que acaba contando sua história de vida "estúrdia", na qual, por um tempo, viveu amasiada com quatro homens simultaneamente. Entremeando as reflexões de Lalinha com memórias de sua vida e sua chegada ao Buriti Bom, passando por seu casamento desfeito com Irvino, registra-se a crescente intimidade entre a moça da cidade e Maria da Glória, até que um inusitado encontro noturno com Liodoro dá inesperada direção e novo significado à sua estada no sertão. Após o adoecimento e a morte de Maria Behú, intensifica-se a tensão erótica entre Lalinha e Liodoro, enquanto Maria da Glória revela que obrigara Gualberto e ter relações com ela. Uma carta noticia o nascimento do filho de Irvino com "a outra", pivô de sua separação com Leandra. Diante desse cenário, a jovem citadina anuncia seu imediato retorno e essa parte se encerra com a iminente consumação da atração entre genro e nora.

Por fim, na terceira e última parte, novamente a perspectiva adotada é a de Miguel, também por meio do narrador em terceira pessoa. De extensão bem menor em relação às anteriores, registra a parada de Miguel na propriedade de Gualberto, quando se noticia que Dona-Dona enlouquecera. O retorno do jovem tem como objetivo dirigir-se ao Buriti Bom a fim de pedir a mão de Maria da Glória em casamento.

\section{Palmeira do Curupira}

Logo no início da narrativa, numa mirada ao Buriti Grande, registrase a seguinte passagem: 
“Eh, bonito, bão... Assunga... Palmeira do Curupira..." Tinha dito o Chefe Zequiel, bobo risonho. Como o Curupira, que brande a mêntula desconforme, submetendo as ardentes jovens na cama das folhagens, debaixo do luar. (B, p. 126) ${ }^{1}$

Além da explícita menção ao ente mítico e sua ação erótica, associadas à figura da palmeira, note-se, no detalhe da fala do "bobo" a fórmula ("bonito, bão") que anos mais tarde apareceria na fala de Tonho Tigreiro, mestiço, narrador de "Meu tio o Iauaretê": "onça pensa só uma coisa - é que tá tudo bonito, bom, bonito, bom, sem esbarrar". ${ }^{2}$ (ROSA, 1976 - grifo meu).

A nomeação explícita que liga a palmeira descomunal a um dos entes mais conhecidos da cultura dos povos originários parece mais do que suficiente para justificar a investigação da relação de "Buriti" com essa tradição específica.

O Curupira, de acordo com João Barbosa Rodrigues (1890, p. 4) em seu Poranduba amazonense, tem o hábito de bater nas árvores para ver se estão firmes usando seu pênis "que é de tamanho extraordinário". ${ }^{3}$

Logo na sequência, outra menção: "Como o Curupira, que brande $a$ mêntula desconforme, submetendo as ardentes jovens, na cama das folhagens, debaixo do luar." (B, p. 126, grifos meus). Ora, essa personagem, segundo o mesmo Barbosa Rodrigues, é o "gênio protetor das florestas e da caça, que castiga os que as destroem" (Idem, p. 6). Mais adiante, o autor aponta uma das possíveis variantes do ente, das montanhas peruanas, "onde é uma espécie de sátiro, cabeludo até a cintura, quase negro e raptor de mulheres que leva para suas orgias" (Idem, ib. - grifo meu).

Voltando a "Buriti", é possível entrever, no amálgama que compõe um personagem como iô Liodoro, algumas semelhanças com o Curupira. Liodoro é protetor da mata virgem, marginal, que cerca o Brejo do Umbigo, a qual ele não consente que seja derrubada (B, p. 102). Ainda, segundo o parecer de seu compadre Gualberto, ele não dá licença para que se cace em suas terras (B, p. 92). Quanto à propriedade do Buriti Grande, a palmeira fica nas terras de Gualberto, mas este a concede, ainda que por "bizarria", mediante "escritura" (B, p. 102) ao seu legítimo proprietário, iô Liodoro, parente do Curupira.

Sua índole sexual, de "garanhão ganhante", é explícita na novela, constituindo parte importante da trama. Embora não haja referência a orgias da parte de Liodoro, é certo que ele tem suas "mulheres exatas". Ao relembrar a chegada de Lalinha ao Buriti Bom, o narrador anota: "Assim a

\footnotetext{
1 Todas as referências a "Buriti" serão aqui apresentadas com a inicial B, seguida do número da página e referem-se à edição Noites do sertão. Rio de Janeiro: José Olympio, 1969 (4 ${ }^{\mathrm{a}}$ ed.).

2 Suzy Sperber (1992) esclarece a origem grega subjacente ao coloquial "bom, bonito" do onceiro, associando-os àquilo que é virtuoso e belo, segundo o conceito de kalós-kagathos da paidéia.

${ }^{3}$ Dentre o material do arquivo pessoal de Guimarães Rosa disponível no IEB, o caderno 14 traz uma menção ao volume de Barbosa Rodrigues aqui citado.
} 
viagem a aturdia - consumava-se como um rapto" (B, p. 152 - grifo meu). O dicionário Houaiss (2001, p. 2385) define rapto como "crime que consiste na subtração de mulher honesta, de um local para outro, tendo em vista fins libidinosos, utilizando violência ou grave ameaça". Outras acepções possíveis para esse vocábulo são "rápido, veloz" e "em êxtase; enlevado, arrebatado".

É sugestiva a aproximação do proceder selvagem do Curupira, "raptor de mulheres" e a comparação estabelecida pelo narrador entre o empreendimento de Liodoro e um rapto. A violência associada ao rapto no dicionário não se dá na novela, a não ser que se leia na decisão do patriarca alguma violência velada em nome da manutenção das aparências e dos bons costumes. Lalinha dá seu consentimento à proposta. Mas o mesmo dicionário aponta para a variante do "rapto consensual".

Quanto ao sentido de êxtase e arrebatamento, esse talvez não esteja aparente na viagem, programada e executada ao seu tempo sem maiores surpresas, mas certamente é perceptível nos encontros noturnos entre Lala e Liodoro, nos quais se deixa entrever esse estado que tira a ambos do cotidiano ordinário, enlevando-os num "brinquedo" todo singular, "inconcebível, arrebatador como se lido e escrito" (B, p. 217 - grifo meu).

\section{2. Éden brasílico: o buriti e as origens}

A associação do Buriti Grande ao Curupira pode servir ainda como porta de entrada para uma investigação mais aprofundada sobre a valoração simbólica do buriti na cultura das nações nativas. Afinal, em que medida a simbologia contida nas narrativas e outros dados da cultura dos povos originários poderiam servir, ou não, como elemento que possibilitasse uma nova visada interpretativa para a novela de Guimarães Rosa?

Do pioneiro estudo de Cavalcanti Proença à recente contribuição de Luiz Roncari - para citar apenas dois entre os muitos estudos - constata-se a relevância do buriti na obra desse autor. Seja a palmeira que se espalha ao longo dos contos e do romance de Rosa, ou o "Buriti" que intitula a novela que encerra o Corpo de baile, facilmente se constata a relevância simbólica desse elemento na produção do escritor mineiro.

Mesmo sendo um dos mais importantes símbolos da obra de Rosa, evidente em sua exuberância literária, o buriti pode passar despercebido quanto à sua conexão não só com a história do país, como com o imaginário tradicional. A conexão está ali, mas é como se não estivesse.

A crítica, talvez porque o autor mineiro nada indique a esse respeito, passa ao largo do fato de que a palmeira nativa do Brasil existe há séculos e liga-se a uma tradição milenar muito antes de ser parte da criação literária de Rosa. Antes de ser um entre tantos signos do denso texto de um Grande 
sertão: veredas, é elemento constitutivo de outro sertão, um denso bioma, o cerrado.

Sabe-se que essa palmeira é tão antiga quanto os primeiros habitantes dessa terra e que, como eles, tenta resistir às trágicas consequências do contato com o europeu. Para o antropólogo Altair Barbosa, "as plantas do cerrado são de crescimento muito lento. Quando Pedro Álvares Cabral chegou ao Brasil, os buritis que vemos hoje estavam nascendo. Eles demoram 500 anos para ter de 25 a 30 metros" (BARBOSA, 2014). O que não dizer da antiguidade do Buriti Grande, centro gravitacional ao redor do qual orbitam as personagens de "Buriti" e sua singular eroticidade: "antigo de velho, rijamente. Calculado em altura de setenta e tantos metros." (B, p. 102).

E é justamente por esse viés da evocação de uma ancestralidade mítica que se pode iniciar uma pesquisa sobre a ligação da literatura de Guimarães Rosa, e especificamente de "Buriti", com a cultura dos povos originários do Brasil. Ou seja, toda vez que o leitor passa por este vocábulo no texto rosiano, passa, necessariamente, embora sem se dar conta, pela lembrança de um passado propriamente nativo.

Tal evocação, ainda que no plano mítico /literário, é facilmente encontrada nas páginas de "Buriti", quando o narrador menciona, mais de uma vez, o Jardim do Éden, ao falar do ambiente da ação:

Dona-Dona precisava da maior bondade do próximo, não era imaginável entre as belas grandes árvores, num jardim da banda do oriente, num lugar de agrado (B, p. 105)

[...] o sonho era a princípio um jardim de grandes árvores de bela vista, da banda do nascente, um lugar de agrado (B, p. 99)

Ali, o jardim, de Deus, o laranjal, a noite azulante (B, p. 244)

Vê-se aqui a evidente ligação do ambiente da ação com o jardim que enseja a criação do homem segundo a tradição judaica. Menos evidente é a possibilidade de relacionar o buriti com este mesmo sentido de algo ligado às origens, com exceção feita, talvez, à presença do Buriti Grande.

Além dessa explícita referência ao mítico Curupira, que evoca ainda parte do erotismo que se encontra em "Buriti", não é difícil encontrar a ligação do buriti com diversos mitos de origem, além do fato da palmeira ser elemento indispensável à constituição do modo de vida de diversas etnias.

Vide, por exemplo, a observação do etnólogo alemão Curt Nimuendajú (1942, p. 62), ao escrever sobre os Xerente: "the split leaflets of the burity offer so important and so widely usable a material in basketry and for tying that it is hardly possible to picture the ancient Serente without burity". ${ }^{4}$

\footnotetext{
${ }^{4}$ Tradução minha: as tiras das folhas de buriti oferecem material tão importante e tão amplamente usado na confecção de cestas e para amarrações que é muito difícil imaginar os antigos Xerente sem o buriti.
} 
Uma breve leitura de algumas narrativas permite constatar a presença do buriti compondo a ambiência dos mitos de criação do mundo, quando seus habitantes não eram ainda humanos, mas o Sol e a Lua, ambos do sexo masculino. Uma destas histórias, recolhida por Nimuendajú, traz a Lua (Wáire) que fica com inveja ao ver que as fezes do Sol (Waptokwá) ficaram vermelhas depois de ele ter comido os frutos do buriti (NIMUENDAJÚ apud WILBERT; SIMONEAU, 1984, p. 35).

Mais do que mero elemento constitutivo da paisagem mítica, da origem dos tempos, o buriti entra na formação do próprio homem.

Segundo a tradição Mehim - nome pelo qual os Krahôs se autodenominam ${ }^{5}$-, recolhida por Pompeu Sobrinho (cf. 1935, p. 203), "no começo do mundo não havia gente; na terra apenas viviam Pud (sol) e Pudlêra (lua), que moravam juntos e eram compadres". Pud fez o buriti, assim como as ferramentas para trabalhar, sem o conhecimento do outro. Como na lenda recolhida por Nimuendajú, Pudlêra inveja as fezes vermelhas de Pud. Respondendo à indagação do compadre, Pud afirma que isso acontecia por comer as flores de pau d'arco. Como não obtivesse o resultado esperado comendo essas flores, Pudlêra se queixa a Pud que, então, aponta para os frutos do buriti, que são comestíveis quando maduros. Mas Pudlêra come os frutos ainda verdes, que não eram bons. Aborrecido, joga os caroços no buriti. A palmeira, que era baixa como um arbusto, "cresceu de repente e ficou alta, como é agora" (Idem, p. 304). Um dia, Pud e Pudlêra foram nadar no rio. Pud cortou talos de buriti e jogou no rio. Esses afundaram e, depois, vieram à tona, "mais limpos e mais bonitos, transformando-se em pessoas de boa aparência. Os filhos de Pud são por isso alvos e bonitos, de cabelos lisos e compridos" (p. 207). Pudlêra repete o gesto do compadre, mas os talos, virados gente, logo surgiam "sujos e feios":

Os filhos de Pud e os de Pudlêra espalharam-se pelo mundo e é por isto que em toda parte há gente bonita, limpa, alva, de cabelo liso e comprido e gente feia, suja, preta, de cabelo assanhado e curto. Povoado o mundo, Pud e Pudlêra resolveram subir para o céu [...] (POMPEU SOBRINHO, 1935, p. 207-8)

Em “Buriti" é possível ver não só a referência ao Buriti Grande como uma expressão de uma antiguidade mítica, mas também como uma pessoa:

O Chefe falava do buriti-grande, que se esse fosse antiquíssimo homem de botas, um velho, capataz de, de repente, dobrar as pernas - estirava os braços, se sentava, no meio da vargem. Morto, deitado, porém, cavavam-lhe no lenho um cocho, que ia dessorando até se encher de róseo sangue doce, que em vinho se

5 Segundo consulta ao site do Instituto Sócio Ambiental, disponível em: https://pib.socioambiental.org/pt/Povo:Krah\%C3\%B4, acesso em: 21/05/19. 
fazia; e a carne de seu miolo dava-se transformada no pão de uma grumosa farinha, em glóbulos remolhada (B, p. 126 - grifo meu)

A fortuna crítica dessa novela já assinalou a aproximação de iô Liodoro com a palmeira descomunal, bem como a presença do buriti no sobrenome da família, na relação do nome científico Maurítia vinífera com o Maurício de Liodoro e no nome de sua mãe, Vovó Maurícia. Chama a atenção a relação tão estreita dessa família com a palmeira, sendo mesmo indissociáveis no nível de sua nomeação. A narrativa Krahô, por sua vez, aponta para a vinculação primeira entre a "carne" e o "sangue" a que o trecho acima se refere, desse "antiquíssimo homem", ancestral mítico, e a origem mesma do homem, segundo essa etnia.

Nesse mesmo trecho de "Buriti", é inegável a menção à experiência cristã, do sangue que se faz vinho e da carne transformada em pão. Admitindo-se a possibilidade de unir o Buriti-Grande, "velho capataz", com a tradição do índio, que afirma que o homem foi criado a partir de talos do buriti, é lícito afirmar que a passagem aponta para o sincretismo de tradições. Ainda que se argumentasse que esse velho capataz pudesse ser uma referência ou alusão ao próprio Cristo, lembre-se que aqui ele é o próprio buriti.

Observe-se que a narrativa Krahô ainda faz a distinção entre a beleza dos filhos de Pud, nascidos da união dos talos de buriti com as águas do rio, e a feiura dos herdeiros de Pudlêra.

Maria da Glória - filha de Liodoro e legítima descendente do buriti que traz em seu nome - é descrita como sendo solarmente bela ("como não se olha o alagável do sol" comenta Miguel sobre a dificuldade de olhar para ela). Com seus cabelos aloirados, é a herdeira dessa nobre e mítica árvore genealógica. Quanto a Lalinha, embora não seja descendente da casa, mas ligada a ela pelo matrimônio, esta é louvada, tal qual Maria da Glória, por sua alva beleza: "Se Dona Lalinha se despisse, não sonho como seria. Um corpo diferente de todos, mais fino, mais alvo [...]" (B, p. 89).

Em contraposição às belezas radiantes das jovens, encontra-se a feiúra "tisna, ${ }^{6}$ encorujada" (B, p. 94) de Maria Behú, junto com outra figura que, pela aparência, parece resultado do empreendimento de Pudlêra: Dona-Dona, descrita nesses termos pelo narrador:

Dona-Dona, quando aparecia, não escondia sua infelicidade. Ela mesma era roxa, escura, quase preta, dessa cor que semelha sujeira em pele. Com um desajeitado pano à cabeça, ocultava seus cabelos, $\mathrm{o}$ encarapinhar-se. (B, p. 105 - grifos meus)

\footnotetext{
${ }^{6}$ Segundo o Dicionário Houaiss (HOUAISS, p. 2726), tisna significa "substância preparada para dar tonalidade enegrecida a qualquer coisa", tendo a mesma raiz que a palavra "tição". Tisnar é sinônimo de enegrecer, sujar, macular.
} 
As relações de proximidade do texto de Rosa com a narrativa colhida por Pompeu Sobrinho, no tocante à descrição dos filhos da Lua / Pudlêra são significativas, visto que o escritor cearense os qualifica como sendo "gente feia, suja, preta, de cabelo assanhado - ou enroscado - e curto".

A importância da lua em "Buriti" já foi estudada, na perspectiva da astronomia clássica grega, no volume $A$ raiz da alma de Heloísa Vilhena de Araújo. Essa autora aponta para as insistentes referências lunares e sua ligação com o feminino e a fertilidade. A leitura da novela permite ainda, facilmente, perceber a relação da lua com a loucura, de acordo com o ideário popular, registrado por Câmara Cascudo (1988, p. 443 e segs.).

A lua, além de ser a mãe dos vegetais (CASCUDO, 1988, p. 443) - e em "Buriti" a importância das flores, frutos e palmeiras já foi demonstrada (MACHADO, 1991) - é conhecida por afetar o juízo ou influenciar o humor dos, assim chamados, lunáticos. Ou, nas palavras das mulheres da cozinha, "Olhe: pior, para cristão, é quando a lua tira o juízo..." (B, p. 209). Entendese aqui loucura no sentido mais amplo, daquilo que se opõe à razão ou ao "juízo", levando o sujeito a agir de forma disruptiva, ignorando os limites estabelecidos da vida em sociedade.

De amplo apelo popular, a associação dos loucos com a lua ${ }^{7}$ foi também estudada em outro momento por [trecho removido para preservar a avaliação às cegas], sendo que a existência do astro no firmamento, no imaginário nativo, pode também ser resultado de um amor incestuoso. ${ }^{8}$

Ao final de "Buriti", quando Miguel para na propriedade de Nhô Gualberto, ao anoitecer, constata-se que Dona-Dona enlouquecera. Não é demais lembrar que a união de Maria da Glória com Gualberto traz, em si, uma carga relativa de incesto, pois o fazendeiro é denominado "compadre", aquele que substitui o pai. Mas a associação entre a lua e a sorte da mulher de Gualberto se dá de forma indireta: "A casa da Grumixã datava de século. Agora ela consistia, mais ciente, mais, do que mesmo se houvesse grande luar e a gente visse e ouvisse uma coruja-grande ulúl, na estranha risadeira de pios, apousada sobre o meio de sua cumeeira" (B, p. 246 grifo meu). Tal é a sorte de Dona-Dona, que se aproxima de sua comadre ${ }^{9}$ Maria Behú, falecida na lua nova, aqui aludida na figura da coruja.

Coruja e buriti, por sua vez, voltam a se encontrar na tradição Xavante. Na narrativa de Jerônimo (cf. GIACCARIA e HEIDE, 1975, p. 282; 286), antigamente havia uma coruja chamada Hö'A que cantava para agradar seu dono. "Quando ela via algum bichinho, pegava e encostava na casa, e voltava no lugar. [...] 'Acho que pegou algum bichinho. À noite

\footnotetext{
${ }^{7}$ Registre-se aqui a observação feita por Michel Foucault, em sua História da loucura na Idade Clássica (1991, p. 13), de que a "lua, cuja influência sobre a loucura foi admitida durante séculos, é o mais aquático dos astros". A água, como se sabe, é abundante na propriedade do Buriti Bom. 8 Ver a esse respeito Barbosa Rodrigues (1875) ou Mindlin (2007) e Mindlin (1998).

${ }^{9}$ Lembrando que, assim como Gualberto trata Liodoro, informalmente, por "compadre", o mesmo se dá com Dona-Dona em relação a Behú: "'Comadre Maria Behú...' - ela dizia. Explicava: combinação delas. Tivesse tido um filho, Maria Behú seria a madrinha" (B, p. 105).
} 
enxergava bem'" - disse o dono. Um dia, ao ouvir a coruja cantar, o dono sente saudade. Ele diz: "Sim, estou com saudade mesmo, vai acontecer alguma coisa com ela. [...] A saudade é assim mesmo, o canto dela me desperta a saudade. Vai morrer mesmo". Nesse tempo, os Xavantes não conheciam a morte ou tampouco a doença. A coruja para de cantar e tomba morta no chão. $\mathrm{O}$ dono, muito triste, se põe a chorar, mas não conta com a compreensão dos demais membros da tribo, pois, afinal, era apenas uma coruja, não era um Xavante. Alguns chegam a dizer que, no lugar do dono, assariam a coruja ao invés de pranteá-la. Em retorno, ouvem a resposta: "quando se gosta de um animal, é assim mesmo". Mesmo sem entender direito o motivo, pois não se tratava de um ser humano, começam a cavar a sepultura e a fazer outros preparativos rituais para o funeral. Ninguém parece entender o motivo de tanta tristeza e o porquê de se enterrar um animal com o mesmo cerimonial que se enterra um humano. Mesmo assim, o enterro se consumou, e os donos da coruja choraram sua morte por vários dias. A partir da morte e do sepultamento da coruja, apareceram a doença e a morte entre os Xavante. Passou a existir a sepultura e aqueles que morriam eram enterrados da mesma forma que esse animal. Passado um tempo, o dono da coruja pediu que se cortasse o buriti, para que fizessem uma celebração: "Vão cortar o buriti, vão cortar o buriti. Para fazer a festa, para me agradar e esquecer o morto." Desde então, os Xavante passaram a ter a corrida com toras de buriti.

Diversos são os trechos de "Buriti" nos quais se insiste no caráter "retirado de rota" da propriedade do Buriti Bom, sua feição próxima à lenda e, na perspectiva de Lalinha, como um lugar estagnado, no qual "nada se realizava", "daquela casa, que parecia impedir os movimentos do futuro" numa recusa "ao que deve vir" (B, p. 191). Um lugar fechado próximo do tempo mítico, circular -, em estado de suspensão, pois o "que deve vir" - próprio do tempo histórico, inexorável em sua passagem -, tanto pode ser a vida quanto a morte. Lugar próximo, portanto, à comunidade Xavante e seu estado primordial, imunes ao adoecimento e à morte.

A jovem citadina ocupa-se das questões relativas a Eros e reconhece que a chegada de Miguel ajudara a romper a relativa estagnação da propriedade, devido ao enamoramento de Maria da Glória por ele. Num lugar em que a atividade erótica parece se restringir ao patriarca, agora a libido começa a circular também entre as jovens mulheres.

A contrapartida de Eros, Tânatos, também entra na equação. Maria Behú, que em vida se mortificara, em rezas e penitências, morre pouco depois da chegada da carta que revela o nascimento do legítimo herdeiro de Liodoro e, assim, desfaz oficialmente o laço que prendia Lalinha à família. No comentário de uma das mulheres da cozinha após a morte de Behú: "Bem dizia sempre o Chefe: que risadas, que corujas..." (B, p. 239). E é justamente a morte da coruja Behú que precipitará - não antes do devido 
luto, "segundo as regras antigas" (B, p. 239) - tanto a revelação de que Maria da Glória dormira com Gualberto, quanto o encontro propriamente sexual entre Lalinha e Liodoro, não esquecendo a melhora súbita do Chefe Zequiel.

A coruja, na narrativa Xavante, representa o caráter intocável dessa etnia, imune à passagem do tempo, ao adoecimento e à morte. Só após a morte do animal, sem causa aparente, a comunidade entende o sentido do adoecimento e da finitude. Assimilar tais fenômenos à sua vida até então incorruptível representa um choque, motivo de longo pranto. Mas, após o luto, a possibilidade de realegrar-se e alternar a dor com a alegria mostrase exequível, sendo essa a função da corrida de toras de buriti. Tal prática, ademais, pode ser encontrada em diversas etnias. Entre os Xerente, por exemplo, existe a tradição da corrida de toras de tronco do buriti, ornamentadas pelo pajé com a finalidade de pedir a proteção dos espíritos da mata. ${ }^{10}$

A saudade que o Xavante percebe no canto da coruja anuncia a morte que não se restringirá ao próprio animal, mas atingirá, então, toda a comunidade. A presença da coruja, entre o cantar e o caçar pequenos animais, atesta a reafirmação do mesmo sempre idêntico, o eterno retorno. A "encorujada" Behú, nas suas repetidas rezas e penitências, cumpre função análoga, na medida em que, no dizer de Susana Lages (2002, p. 124), "Behú vive o tempo morto da repetição das rezas, da negação do tempo enquanto agente da metamorfose dos seres e das coisas".

A morte de Behú, representante mor das virtudes repressoras, parece lembrar a todos a passagem do tempo. Morte que traz, depois do devido cerimonial, o renascimento da vida, com a força de Eros que se manifesta de forma inconteste no final da segunda parte da novela. Na narrativa Xavante, se não há a profusão erótica do texto literário, há o buriti que, cortado em toras, reinaugura o tempo das alegrias, ajudando a superar a perda da coruja.

A coruja ainda é mencionada num dos registros da paisagem sonora do Chefe Zequiel (B, p. 141; 142), num ataque a uma "vítima" (ROSA, 2003, p. 105; 106), com uma profusão de onomatopeias que o autor explica ao seu tradutor italiano. Em sua correspondência, Rosa se refere ao Chefe Zequiel, "em sua instabilidade de primitivo, se entusiasmando com o poderoso, isto é, com o agressor, se identificando com ele, com a coruja, e deliciando-se com a presteza da cena" (Idem, p. 106). Mais adiante, sobre o trecho "as criaturas estão fazendo corujas" (B, p. 142), o autor esclarece Bizarri: "normalmente, as pessoas que dormem estão dando origem aos seres hostis da noite" (Idem, p. 107).

10 Disponível em: http://cidadaniaejustica.to.gov.br/noticia/2015/8/17/povo-indigenaxerente-apresenta-a-forca-de-sua-cultura-e-tradicao/, acesso em: 17/04/2017 e em: https://pib.socioambiental.org/pt/povo/xerente/1173, acesso em: 17/04/2017. 
O intento de Rosa é associar a coruja à hostilidade, aos perigos da noite, sua violência, seu poderio, propiciadores do medo, "O senhor tema. Unha de coruja pega bichinho, ratos, i-xim, que nem anel num dedo" (B, p. 142). Essa dimensão extrapola qualquer relação com a narrativa Xavante apresentada acima. Mas, assim como Zequiel se entusiasma com a ação da coruja, no mito, o dono do animal, que nutre grande afeto por ele, fica atento às investidas da coruja aos bichinhos.

\section{3. "Estado aquoso" / Demorados femininamente"}

Assim Miguel, já enamorado de Maria da Glória, se refere aos buritis: "O buritizal, acolá, impunha seu estado aquoso, os buritis eram demorados femininamente" (B, p. 128).

Parece difícil conciliar, num primeiro relance, a feminilidade de um elemento referido no masculino: o buriti, o buritizal.

A associação primeira do buriti ao elemento feminino talvez nos escape no momento, demandando pesquisa ainda mais acurada. Mas a cultura dos povos originários mostra a união do buriti com a feminilidade como um traço corriqueiro, supõe-se que de longa data e, nesse sentido, "demorado": algo que começou na aurora dos tempos e permanece indefinidamente.

Segundo o registro de Curt Nimuendajú, entre os Apinajé: “No começo da gravidez, procuram determinar o sexo do feto, amarrando na barriga da mulher grávida um cordão de fibra de buriti, quando querem uma menina e de envira, quando querem um menino" (NIMUENDAJU, 1983, p. 78).

Outra significativa relação entre o buriti e o feminino, é o uso do ulurí, "o cinto da mulher", entre as tribos do Alto Xingu. Segundo os irmãos Orlando e Cláudio Villas-Bôas:

A importância do ulurí é muito maior do que a de um simples
cinto. Ele transfere à mulher a opção e a regularidade das
relações sexuais. A iniciativa sexual é exclusiva das mulheres,
uma vez que um homem jamais encosta a mão no ulurí. O cinto
é um feixe de fios de seda do broto do buriti, com a qual as mulheres
envolvem a cintura. Na parte da frente, cobrindo parcialmente o
órgão genital, um pequeno triângulo de entrecasca de árvore; do
vértice inferior desse triângulo sai um fio que, passando entre as
pernas e as nádegas da mulher, vai se prender na parte de trás
do cinto. No momento em que a mulher entra no período
menstrual, o fio é retirado, mas o cinto permanece. (VILLAS-
BÔAS; VILLAS-BÔAS; BISILLIAT, 1990, p. 21 - grifo meu)

Nesse caso, note-se que não apenas o feminino, mas as práticas sexuais dessas etnias passam pela mediação simbólica desse artefato feito a partir de um subproduto do buriti. Como se sabe, "Buriti" traz no seu 
bojo a discussão sobre essa possibilidade das mulheres tomarem certa iniciativa nas práticas sexuais, como é o caso de Maria de Glória e sua singular "opção" que passa pelo agenciamento do compadre Gual em nome de sua satisfação sexual.

Já a associação do buriti com as águas pode ser mais facilmente encontrada. O mesmo Curt Nimuendajú, apresentando uma variante dos mitos de criação onde sol e lua habitam a terra, traz essa ligação (cf. NIMUENDAJU, 1983, p. 123). A lua (Mbuduvri-re) quer que suas fezes fiquem vermelhas como as do sol (Mbud-ti). O sol, sempre enganando a lua, oferece um fruto de buriti com uma banda dura. A lua prova e não acha bom. Revoltada, joga a fruta no tronco do buriti que, naquele tempo, era pequeno como um arbusto. A palmeira cresce e fica do tamanho que tem hoje. O sol protesta: "Ninguém mais pode alcançar os frutos do chão". A lua contra-argumenta, dizendo que "assim era melhor, porque estando com sede, de longe se conheceria o lugar da água, pelas altas palmeiras buriti".

A propriedade do Buriti Bom é louvada por sua riqueza em águas "A terra do Buriti Bom tinha muita água" (B, p. 132) - e pelos buritis em profusão. Difícil saber com exatidão onde se inicia essa associação, uma vez que ela parece estar, justamente, na origem dos tempos, e, por assim dizer, espalhada por toda parte.

Outro exemplo dessa associação pode ser encontrada entre a etnia Gavião-Ikolen, de Rondônia. Para a tradição desse povo (cf. MINDLIN, 2001, p. 70; 72), segundo a narração de Digüt Tsorabá, os espíritos goihanei vivem nos rios, são os espíritos das águas. As filhas do cacique dos goihanei, chamado Malolan, casaram-se com dois homens. Um dia, Malolan, disfarçado de velhinho apoiado numa bengala, foi visitar os genros, advertindo-os de que ninguém poderia falar mal dele. Embora bem recebido por eles, os demais membros da tribo reclamavam do aspecto e do cheiro do velho, maltratando-o. Desgostoso, ele anunciou: "aqui entre as malocas de vocês vão nascer dois buritis. Eu não estou satisfeito com seu povo, não". Nas malocas dos dois genros, fez furos com uma vara nos pontos cardeais e no centro. A água foi jorrando dos furos, alagando toda a terra. Goihan recomendou aos genros e suas filhas que subissem no olho do buriti, pois a palmeira cresceria, acompanhando as águas, e eles não morreriam. Além da água que manava do chão, veio forte chuva, com trovoadas. O rio encheu, inundou aldeias. Quem não era da família virou bicho, lontra ou ariranha. Muita gente morreu. Seguindo a orientação do goihan, quando o buriti deu frutos, jogaram-nos ao chão para saber, pelo barulho, se ainda havia água. Após vários dias jogando os frutos e ouvindo o barulho das águas, finalmente ouviram o ruído do fruto batendo no chão e desceram do buriti. O local ficou conhecido como "o lugar do dilúvio", Paíguib-txikar, um lugar com muito buriti. 
Talvez não se possa avançar muito na investigação dessa união água / buriti e sua participação na trama da novela. Pode-se afirmar, porém, que, da mesma forma que a palmeira está presente nos cenários da criação do mundo e do homem, a água parece inseparável do buriti. Seja no casamento do rio com os talos de buriti, que dão origem ao homem no imaginário Mehim, seja no terreno alagado resultante do dilúvio GaviãoIkolen, resta essa aliança atemporal. ${ }^{11}$

Mais evidente e significativo, levando em conta a associação da água com a fertilidade, é pensar no buriti feminino.

Além do que já foi dito sobre o buriti e sua associação com a água, a questão amorosa - tema que atravessa todo o "Buriti" de Rosa - pode contribuir para entender a ligação da palmeira com a feminilidade. Em pelos menos duas etnias foi possível localizar narrativas que relatam a transformação do buriti em mulher, resultado da admiração e do desejo de um homem em face da palmeira.

Entre os Kamayura, com a narração de Tacumã e Kanutary Kamayura (cf. KAMAYURA, 2003, p. 251; 252), do Mato Grosso, um homem admira a beleza de um buriti e diz: "seria bom se fosse minha mulher". Ao voltar para casa, à noite, uma bonita moça o chama à porta da sua casa. Indagada, a moça responde ser "aquela que você falou que estava querendo como sua mulher. Eu sou buriti." O homem convida-a para entrar, colocando "a rede dela por baixo da rede dele." Inicialmente, a moça fica com o rapaz, mesmo alertada pelos pais dele de que se tratava de alguém preguiçoso. Mas quando o jovem chama atenção para o fato das redes dos seus pais estarem velhas, a jovem toma as redes velhas, queimaas numa panela e, depois de esfriar, dá-lhes redes novas e bonitas. No entanto, as mulheres da aldeia se queixam com o marido dela sobre o fato de sua mulher ter a prática de queimar as redes da família. Um dia, a mulher escuta as críticas indiretamente direcionadas para ela e, magoada, decide ir embora, comunicando o marido de sua decisão. Depois de partir, o marido ainda procura pela moça, sem sucesso. O pai do rapaz o critica, por ter dado ouvido à conversa das outras pessoas. O marido pega uma canoa e vai falar ao buriti: "Poxa! Você podia ser minha mulher!" Mas a moça não retorna.

Narrativa semelhante é encontrada entre os Mehinaku, também do Mato Grosso. A partir da narração de Kutapiene Mehinaku (cf. PAPPIANI e LACERDA, 2017, p. 96-9), registra-se a história e Xepeku, a "mulher buriti que criou a rede". O homem vai pescar no buritizal e vê o broto de buriti, vermelho como o urucum. Era Xepeku. Ele se apaixona pelo broto e pensa: "Que lindo, esse broto! Acho que é uma mulher. Podia ser minha esposa." No dia seguinte, uma mulher o chama à porta da casa. Respondendo ao questionamento do homem, ela se apresenta, “Eu sou Xepeku [...] aquele

11 Vale pontuar que a associação da palmeira com as águas e seu sentido de propiciação da vida, refrigério, descanso e mesmo deleite sexual está presente em outras mitologias, como a egípcia. 
broto de buriti que você gostou ontem. Está vendo? Agora sou uma mulher! [...] Você gostou de mim. Eu também gosto de você, por isso, vim". Entram e vão para a rede. No dia seguinte, chamada pelas cunhadas e cunhados para ir à roça, Xepeku pede para ir no dia seguinte, pois precisava descansar, obtendo a anuência do marido. No outro dia, o casal sai para o banho, e a mulher diz ao marido o quanto as redes de todos da tribo são feias, e promete queimá-las. Questionada pelo marido, ela pede que espere para ver o que acontecerá. No outro dia, as pessoas voltam cansadas da roça, mas não têm onde repousar. Alguém diz que foi a moça nova que havia queimado as redes. A mãe questiona o filho e ele se diz muito envergonhado: "Ela falou que depois vamos ver o resultado. Ela não gostou de nossas redes. Disse que eram feias, que estava com nojo." Não havendo redes para descansarem os índios, todos se sentam. Xepeku pega várias cuias grandes e enche-as com as cinzas das redes queimadas, colocando água em cima delas. Coloca panelas de barro por baixo das cuias furadas, para a cinza pingar. Das cuias vai pingando a cinza, até cada panela ficar pela metade. Então despeja em outras panelas muito grandes, cinco panelas. Tampa e ali mesmo deixa. Ninguém pode olhar, nem mesmo Xepeku. As cinzas que pingaram na panela se transformam em redes. Redes novas e lindas, dentro das panelas, inclusive com a corda para amarrar. A rede do esposo tinha a trama fechada, bem feita, muito especial. A moça pega as redes e começa a amarrar nos lugares certos. Todos ficam olhando, admirados: "quem é essa mulher que faz isso?". Xepeku fica mais dois dias na casa do marido. No terceiro dia, chama-o para pescar. $\mathrm{Na}$ verdade, ela quer ir embora, pois ficou muito triste com todos que reclamaram do fato de ter queimado as redes. E, mesmo triste, ela fez as redes novas para a família. Os dois seguem remando, em direção ao buritizal onde o homem encontrou Xepeku. Chegando lá, a mulher comunica sua intenção. Questionada sobre o motivo, ela responde: "Sua mãe ficou muito brava porque eu queimei a rede dela. Seus irmãos, suas irmãs, sobrinhos, todos ficaram bravos comigo". O marido tenta convencêla a ficar, pois todos estavam animados com as redes novas, e não estavam mais bravos. Ela retruca: "Eles deveriam ter entendido. Deveriam ter esperado para ver o resultado antes de reclamar". O homem pede para que ela não vá, mas não consegue demovê-la da ideia. Xepeku transforma-se novamente em broto de buriti. Ele volta para casa muito triste, chorando. Sua mãe quer saber o motivo, e, depois de relutar, ele diz: "a culpa é de vocês. Por isso ela foi embora. Ela é a mulher-buriti. Não é uma mulher de verdade, não é de outra etnia, não é Kuikuro, Waurá, Yawalapiti, Kalapalo. Ela é uma mulher-buriti, um ser da natureza". "Ah, eu não sabia!", responde a mãe. Pessoas de outras casas se admiram ao ver as redes tão bonitas e querem saber quem é a mulher que as faz. A mãe responde: "ela foi embora. Nós brigamos com ela e ela foi embora". "Mas por que vocês brigaram? O trabalho dela é tão bonito!". O narrador comenta, ao final: 
"Essa é a origem da rede. Antes não tínhamos esse tipo de rede de fibra de buriti. Foi a mulher buriti quem criou. Hoje os seres da natureza não se transformam mais em humanos. No tempo de nossos ancestrais, acontecia assim. Hoje não vivemos mais nesse tempo do poder".

Como se vê, não apenas a feminilidade, mas também o enamoramento, são elementos abundantes no "Buriti" de Rosa. Mais precisamente, nas narrativas originárias, é o olhar do homem que, admirado com a beleza do buriti, passa a desejar que a palmeira seja sua mulher. O domínio de Eros é afeito, portanto, ao buriti na perspectiva do nativo, sendo esse, talvez, o mais significativo elo entre a tradição e o "Buriti" rosiano.

O feliz encontro leva o casal para a rede, figuração do encontro erótico. A mesma rede, ao final, se torna o motivo da separação, pois a mulher-buriti considera as redes feias, quiçá inapropriadas para o amor ou o descanso de acordo com sua perspectiva única de palmeira transformada em gente.

A comunidade, desconhecendo a origem da mulher, trata-a como uma estrangeira qualquer, enamorada do rapaz, e estranha seu proceder exótico, que não se encaixa no cotidiano da aldeia e, ainda, propõe uma ação que mexe profundamente com o hábito de todos: a queima das redes. A incompreensão da tribo ante a forma de agir da mulher, manifesta nas queixas a ela endereçadas, fere fatalmente seus sentimentos, levando-a a optar pelo retorno à forma de palmeira. A mulher-buriti esperava, muito provavelmente, uma confiança e uma compreensão muito além das capacidades humanas, por isso resolve partir. $\mathrm{O}$ buritizal e as águas aceitam-na sem questionamentos. Deixa as redes para o desfrute de todos e a saudade no rapaz, cujo desejo, agora, restará insatisfeito.

A força do feminino em "Buriti" e a afirmação de seu papel ativo no erotismo encenado na novela parecem fora de discussão. Afinal, é de Vovó Maurícia, na lembrança de Maria da Glória, a máxima de que o casamento é feito para "Lua-de-mel, luas-de-méis". A matriarca da família tem praticamente o mesmo nome que o buriti, na perspectiva científica: Mauritia vinífera. A família, além do evidente exercício diário de Liodoro e suas mulheres exatas, tem a legítima herdeira, Glorinha, fruto do "buriti mais altaneiro", na fala de Miguel.

A jovem filha de Liodoro, por seu turno, não deixa de inovar, contrariando as expectativas sociais de seu meio: praticamente força o compadre Gualberto a manter relações com ela, deixando de lado a relativa passividade culturalmente associada à mulher e agindo ativa e masculinamente, como seu pai. Embora apaixonada e aguardando o retorno do "príncipe encantado / arcanjo" Miguel, Glória busca saciar sua libido com o vizinho, sabidamente estéril. É certo que essa "nova rede" é trançada em seu íntimo e a ação é mantida em segredo. 
Mesmo a flor da cidade, Lalinha, enxertada na família por seu casamento com Irvino, assume papel ativo e criador "enredando" o patriarca no jogo de sedução, ou "brinquedo", nos encontros furtivos da noite do Buriti Bom.

No texto de Rosa, Maria da Glória e Lalinha pegam as velhas redes da tradição, com seus padrões de comportamento erótico relativamente estanques e tecem, por meio de seus devaneios, palavras e ações, novas redes, inovações que, se não revolucionam o modus vivendi do Buriti Bom, abrem novas possibilidades no desenvolvimento da narrativa e na imaginação do leitor, deixando marcas nas personagens masculinas com quem experimentaram essas novas redes. Conjecturando: Gualberto e Liodoro não sentirão a falta de suas mulheres buritis, Glorinha e Lalinha, quando estas partirem para seus respectivos destinos anunciados?

\section{O recado do buriti}

Se em "O recado do morro", o Morro da Garça dispara, com sua força telúrica, a mensagem que renderá, ao final, a canção redentora, em "Buriti" temos algo bastante distinto. A força do elemento natural é evidente por si mesma na novela, além de ser uma constante na obra de Guimarães Rosa. A natureza comunica-se constantemente com as personagens humanas, cabendo estar atento a tais mensagens e suas possibilidades de decifração.

No lugar do morro, em "Buriti" temos "a treva falando nos campos" (B, p. 114) e o Chefe Zequiel, que ouve aquilo que está muito além de suas capacidades, "escuta o que para ouvido de gente não é" (B, p. 106), perscrutando a voragem noturna como um atalaia bíblico, uma sentinela.

Mas não deve ser à toa - pois dificilmente se poderia falar em "coincidência" na prosa rosiana - que esse personagem se faz mensageiro de tantos "recados" subliminares da tradição do índio: é ele quem denomina o Buriti Grande de "Palmeira do Curupira", além de ver na palmeira descomunal o homem ancestral da tradição Krahô (B, p. 126). É no meio do registro de suas noturnas paisagens sonoras que o narrador se refere à Cobra Grande $(B, p .115)$, além de nomear seu temor relativo à coruja Behú, anunciadora da doença e da morte para os Xavante.

Esse mesmo Chefe, ao receber a visita de Lalinha e Maria da Glória, apresenta seu roçado de amendoim (planta nativa da América do Sul, do tupi, mandu'wi, "enterrado"), narrado nesses termos:

O chão ali era bom e a terra clara - ah, como carecia de ser, ele em seu papagueio explicava. Porque o amendoim, quando produz, abaixa os ramos, para enterrar uma por uma as frutas, escondendo-as; e elas tomavam na casca a cor da terra. Mas já tinha perdido a esperança de colher bastante. - "é porque estou caipora..." - dizia. (B, p. 180 - grifo meu) 
O caiporismo, falta de sorte, azar, de uso popular, é o que explicaria a má colheita do amendoim, segundo o próprio Chefe. Caipora pode ainda ser aproximado, segundo Câmara Cascudo (1988, p. 177), ao Curupira, sendo uma das variantes possíveis desse ente, que pode trazer o infortúnio, ou até a morte, aos que não respeitam as regras e os acordos referentes à proteção da caça e das árvores.

Mas o curioso dessa passagem deve-se ao fato do cultivo do amendoim, da semeadura à colheita, ser de responsabilidade exclusiva das mulheres, segundo o cronista Gabriel Soares de Sousa e seu Tratado descritivo do Brasil em 1587:

Plantam-se estes amendoís em terra solta e úmida, em a qual
planta e benefício dela não entra homem macho; só as índias os
costumam plantar, e as mestiças; e nesta lavoura não entendem
os maridos, e tem para si que se eles ou seus escravos os
plantarem, que não hão de nascer. E as fêmeas os vão apanhar; e
segundo seu uso hão de ser as mesmas que os plantem [...]
(SOUSA apud CASCUDO, 1988, p. 46-7)

Somada à desgastante rotina de passar as noites escrutando seus mínimos rumores, a falta de sorte do Chefe em seu roçado de amendoim não poderia ter relação com o não respeitar esse antigo costume? Além disso, esse estado caipora não indicaria a relativa proximidade de Zequiel com o universo dos povos originários e, portanto, sua sensibilidade a essa tradição, à qual ninguém mais "dá ouvidos"?

A audição do Chefe, que, "por erro de ser" vai muito além do "confim de ouvir" (B, p. 106) de sua espécie, possibilita uma percepção privilegiada dessa "sinfonia da noite no mato" (expressão de Edoardo Bizarri). Do que se depreende do registro feito pelo narrador, está ali o recado da violência latente do sertão e suas terríveis fantasmagorias.

Mas não haveria também, no complexo amálgama usado por Rosa ao forjar suas personagens, um traço dessa capacidade de ouvir e interpretar esses sinais, típica daqueles que originariamente habitavam os sertões? Por que, afinal, fazer coincidir com essa personagem e sua esfera de comportamentos possíveis na narrativa - sua escuta, suas máximas, suas práticas - tantas referências cifradas ao universo do índio? A titulação do personagem, "Chefe", não poderia se associar a um chefe de uma remota e hipotética tribo? Quando, em sua correspondência com Bizarri, o autor mineiro chama o Chefe de "primitivo", considerando a ambiguidade desse termo, não seria possível ler aí uma menção ao nativo, ainda que numa chave depreciativa?

Como se vê, a profusão de perguntas, resultado do que foi elaborado até aqui, indica mais uma encruzilhada entre o universo de Rosa com a 
cultura dos povos originários, não destituída de relevância simbólica e suscitando novas veredas interpretativas.

Por outro lado, se "Buriti" é uma novela da alta vibração erótica e essa se liga ao Buriti Grande, é possível identificar, de maneira difusa, esse parente vegetal do Morro da Garça na sua força transmissora de um recado associado miticamente a Eros - tanto na menção ao Curupira quanto na narrativa da mulher-buriti: "O Buriti-Grande: que poder de quieta máquina era esse, que mudo e alto maquineja?" (B, p. 114).

Atente-se para os adjetivos afeitos ao universo sonoro: "quieta", "mudo" e "alto". Além da importância do elemento auditivo nessa novela, indispensável para aquele que quer se orientar nas Noites do sertão, vale destacar essa similitude do Buriti Grande com o morro recadeiro.

A aproximação da palmeira a uma "quieta máquina" que "mudo e alto maquineja" dá a dimensão da influência do buriti sobre os que vivem sob sua égide. $\mathrm{O}$ "poder", aparentemente indefinível, mas certeiro como algo existente, é sentido na sua muda e alta maquinação pelo narrador e pelas personagens, ainda que seu pleno significado escape ao entendimento deles. Essa bela metáfora aponta para o paradoxo de algo que em meio aos barulhos da noite se imiscui mudamente, mas ainda assim se faz irresistivelmente audível, porque precede à esfera dos sentidos e atinge o âmago das personagens que compõem o clã Maurício Faleiros, movendo-os para suas ações de forma inexorável.

Sendo legítima a associação dos buritis, assim como do Buriti Grande, com a cultura dos povos originários, pode-se afirmar que ao menos parte dessa maquinação transmite a muda e alta tradição desses múltiplos povos, trazendo sua riqueza e pedindo do leitor uma atitude mais atenta à sua presença, menos surda aos seus apelos.

As noites do sertão do Buriti Bom irradiam a eroticidade do solar Buriti Grande, como um totem amoroso e que, conforme o exposto, é erótico também em sua raiz nativa.

\section{Considerações finais}

Difícil entender a pouca atenção da crítica às pistas deixadas por Rosa quanto à importância da tradição dos povos originários em relação ao buriti na composição do seu "Buriti". As poucas reflexões feitas aqui, nascidas do cotejo da obra rosiana com as culturas nativas, hábitos e mitologias próprios, é apenas um sinal do quanto o texto do autor mineiro ainda pode nos (re)velar.

Pode-se cogitar aqui um exercício possível de fazer falar parte dessa tradição (quase) esquecida, presente na obra de um autor canônico da literatura nacional, por meio de um estudo mais criterioso de alguns elementos - no caso, o buriti. 
Guimarães Rosa, que durante os anos de 1933 e 1935 trabalhou no Serviço de Proteção ao Índio, órgão federal que daria origem à FUNAI, dedicou-se ao estudo da cultura dos povos nativos (ROSA apud, GALVÃO; COSTA, 2006, p. 15). Se isso é bastante evidente em "Meu tio o Iauaretê", o presente ensaio mostra que há ainda muito o que se investigar sobre a forma do autor mineiro transformar seu interesse pelos primeiros habitantes do Brasil em texto literário.

\section{Referências Bibliográficas}

ARAÚJO, Heloísa Vilhena de. A raiz da alma. São Paulo: Edusp, 1992.

BARBOSA, Altair Sales. "Entrevista concedida a Marcelo Gouveia”, Jornal Opção, 04 out. 2014. Disponível em:

http:/ / www.jornalopcao.com.br/entrevistas/o-cerrado-esta-extinto-eisso-leva-ao-fim-dos-rios-e-dos-reservatorios-de-agua-16970/

CASCUDO, Luís da Câmara. Dicionário do folclore brasileiro. Belo Horizonte: Ed. Itatiaia, 1988 (7 $\left.7^{\mathrm{a}} \mathrm{ed}\right)$.

GALVÃO, Walnice Nogueira; COSTA, Ana Luiza Martins (orgs.). Cadernos de Literatura Brasileira: João Guimarães Rosa. São Paulo: Instituto Moreira Sales, 2006.

GIACCARIA, Bartolomeu; HEIDE, Adalberto. Jerônimo Xavante conta. Campo Grande: Publicação n. 1 da Casa de Cultura, 1975.

HOUAISS, Antonio. Dicionário Houaiss da língua portuguesa. Rio de Janeiro: Objetiva, 2001 ( $1^{\mathrm{a}}$ ed.).

KAMAYURA, Tacumã; KAMAYURA, Kanutary. Histórias Kamayura. Trad. de Kotok Meyuaulat Kamayrura. Belo Horizonte: Literaterras; FALE /UFMG, 2013.

LAGES, Susana Kampf. João Guimarães Rosa e a saudade. São Paulo: Ateliê; Fapesp, 2002.

MACHADO, Ana Maria. O recado do nome. São Paulo: Martins Fontes, 1991. MARTINS, Nilce Sant'anna. O léxico de Guimarães Rosa. São Paulo: Edusp, 2001 ( $2^{\mathrm{a}}$ ed.).

MINDLIN, Betty. Vozes da origem: estórias sem escrita - narrativas dos índios Suruí de Rondônia. Rio de Janeiro: Record, 2007.

MINDLIN, Betty. Moqueca de maridos: mitos eróticos. Rio de Janeiro: Record: Rosa dos Tempos, 1998 (2a ed.).

MINDLIN, Betty (et alli). Couro dos espíritos: namoro, pajés e cura entre os índios Gavião-Ikolen de Rondônia. São Paulo: Senac São Paulo; Terceiro nome, 2001.

NIMUENDAJÚ, Curt. Os Apinayé. Belém: Museu Paraense Emílio Goeldi, 1983.

NIMUENDAJÚ, Curt. The Serente. Trad. de Robert H. Lowie. Los Angeles: The Southwest Museum Administrator of the Fund, 1942. 
PAPPIANI, Angela; LACERDA, Inimá P. (orgs.) Aunaki Kuwamutu Kuwamutu que criou o mundo e outras histórias do Povo Mehinaku. São Paulo: Ikore, 2017.

PERRONE-MOISÉS, Leila. Flores da Escrivaninha. São Paulo: Companhia das letras, 1990.

SOBRINHO, Thomaz Pompeu. "Lendas Mehim". Revista do Instituto do Ceará, Anno XLIX, 1935, p. 189-217.

RODRIGUES, João Barbosa. Poranduba amazonense, ou kochiyma-uara porandub, 1890. Rio de Janeiro: Typ. de G. Leuzinger \& Filhos. Disponível em: http://biblio.etnolinguistica.org/rodrigues_1890_poranduba

RODRIGUES, João Barbosa. Exploração do rio Yamundá. 1875. 99 p. Acervo da Fundação Biblioteca Nacional - Brasil.

ROSA, João Guimarães. Estas Estórias. Rio de Janeiro: José Olympio, 1976 ( $2^{\mathrm{a}}$ ed.).

ROSA, João Guimarães. Noites do sertão. Rio de Janeiro: José Olympio, 1969, ( $4^{\mathrm{a}}$ ed.).

ROSA, João Guimarães. Correspondência com seu tradutor italiano Edoardo Bizzarri. Rio de Janeiro: Nova fronteira, 2003 (3 $3^{\text {a }}$ ed.).

SPERBER, Suzy Frankl. “A virtude do jaguar: mitologia grega e indígena no sertão roseano", Remate de Males, Campinas (12): 1992, p. 89-94.

VILLAS-BÔAS, Cláudio; VILLAS BÔAS, Orlando; BISILLIAT, Maureen. Xingu - território tribal. São Paulo: Cultura, 1990 (1 $1^{\text {a }}$ edição bilíngue).

WILBERT, Johannes; SIMONEAU, Karin. (orgs.) Folk literature of the Ge Indians, vs. I e II. Los Angeles: UCLA, 1984.

Edinael Sanches Rocha é pós-doutorando do Departamento de Teoria Literária e Literatura Comparada da Faculdade de Filosofia, Letras e Ciências Humanas da Universidade de São Paulo. É doutor e mestre em Letras pelo Departamento de Letras Clássicas e Vernáculas da mesma faculdade. Atua como psicólogo e psicanalista. Contato: edinaelrocha@gmail.com

ORCiD: https://orcid.org/0000-0003-0214-4676 